\title{
The Role of a School Leader in Academic Outcomes: Between Self-efficacy and Outcome Expectations
}

\author{
By Paul Schrik* \& Teresa Akinyi Wasonga ${ }^{\dagger}$
}

This quantitative study investigated the relationships among elementary school principals' efficacy beliefs (Instructional, Moral, and Management Leadership), principals' goal expectations for student achievement (expected outcome), and their impacts on actual student achievement. Two hundred and fifty elementary school principals completed an electronic survey seeking information on their self-efficacy, school outcome expectation, actual school outcome, and personal and school demographics. Bandura's Social Cognitive Theory guided the study. Findings show higher significant correlations between principal outcome expectation and actual school academic outcome compared to selfefficacy expectation and actual school academic outcome. Regression analysis revealed that unlike self-efficacy expectation, outcome expectation predicted actual school academic outcome.

Keywords: efficacy expectation, outcome expectation, elementary school principals, school academic outcome, school demographics

\section{Introduction}

Unprecedented legislative mandates requiring the evaluation of principals' work to include the academic outcome of their students is growing even though research has found that the relationship between the principals' work and student achievement is at best indirect (Ingersoll, Sirinides, \& Dougherty, 2018; Gilmore, 2009; Grissom \& Loeb, 2009). According to Krzemienski (2012), principals are working more, but more of their time is directed towards competing demands that are not directly concerned with student achievement. In addition, they feel less appreciated even though they are considered exclusively accountable for the success/failure of their schools. To quote Troutman (2012), "School principals are under extreme pressure to ensure that their schools are experiencing academic success" (pp. 5-6) without regard for their circumstances or contexts. Goldring, et. al. (2009) summarized the complexity of the role of the school principal in these words:

"high academic standards and systemic performance accountability are critical components of school leadership. Increasingly, principals are being asked to ensure that individual, team, and school goals exist for rigorous student academic and social learning by aligning school activities with local, state,

${ }^{*}$ Superintendent, Rockdale Elementary School District 84, USA.

†Professor, Northern Illinois University, USA. 
and federal standards. Furthermore, leaders must hold themselves and others responsible for realizing high standards of student performance" (p. 35)

These conditions of work would challenge the strength of any one's beliefs in their ability to run a school successfully, especially when student academic outcomes majorly define success and principals do not work directly with children. And even though recent school reforms have focused on expanding teachers' roles in decision-making and research has found benefits in collective and shared decision-making process; leaders are especially key to the success of this process, specifically in providing leadership that actively involves all stake holders (Ingersoll, Sirinides, \& Dougherty, 2018).

Other research finds that despite limited control over many aspects of schooling including student demographics; studies on school effectiveness, school climate, and student achievement, "reveal one commonality, the fact that good happenings in schools depend to a great extent on the quality of school leadership" (Norton, 2002, p. 50) including self-efficacy and outcome expectation (Bandura, 2006). These reasonings have contributed to increased school reform legislation that have focused on effectiveness of school principal leadership, specifically in relation to student achievement and school environment (Sanders, 2014; Bryk et. al., 2010).

In such an environment, demands on principals are not likely to decrease, precipitating increased focus on self-efficacy. In their research, Tschannen-Moran \& Gareis (2004) found that principals with greater self-efficacy beliefs were more steadfast in pursuing their goals, more adaptable to their environments, and did not waste time pursuing unsuccessful courses of action.

This relationship between efficacy beliefs and effort in pursuing goals aligns with Bandura's (1977) definition of self-efficacy. Bandura describes self-efficacy as one's estimate or expectation of their ability to execute behavior needed to produce the desired outcomes, influence decisions, or persist with a behavior. In other words, the level of perceived self-efficacy an individual has proportionately influences the choice of activities they participate in, given environmental factors including obstacles and aversive experiences (Bandura, 1977). Self-efficacy also influences thought patterns and emotional reactions. According to Pajares (1996), people with low self-efficacy are likely to believe things are tougher than they are and may develop a narrow vision of how to approach a problem. Further, in his research, Pajares (1996) reported that self-efficacy is contextual, meaning it is "task and situation-specific" (p. 546). Depending on the task, efficacious individuals are "motivated, persistent, goal-oriented, resilient, clear thinkers under pressure...highly committed, determined, resilient, goal-focused, resourceful and effective problem solvers" (Locke as cited in McCormick, 2002, p. 36). In other words, expected or attained levels of efficacy or efficacy expectation depend on: perceived levels of difficulty or chances for success (magnitude), generality across situations (transferability), and/or the strength of one's belief in ability of self (Bandura, 1977). If the perceptions for success, generalizability and belief in oneself are positive and high; there is also the likelihood of higher efficacy levels.

While Badura provided a general definition of self-efficacy, Tschannen- 
Moran and Gareis (2004) used principals as a point of reference explaining selfefficacy as "judgement of his or her capabilities to structure a particular course of action in order to produce desired outcomes in the school he or she leads" (p. 573). Previously, Gist and Mitchel (1992) found that increased self-efficacy resulted in improved work performance in general. Likewise, when considering challenging environments, McCormick claimed (as cited in Leithwood \& Jantzi, 2008) that "leadership self-efficacy or confidence is likely the key cognitive variable regulating leader functioning in a dynamic environment" (p. 497). However, when it comes to the relationship between self-efficacy and student achievement, findings are contradictory. Some research efforts that have examined the relationship between a principal's self-efficacy (Bandura, 1977) and student achievement point towards statistically significant relationships (Lehman, 2007; Virga, 2012; McCullers, 2009; Roley, 2009; Lovell, 2009; Santamaria, 2008; Paglis \& Green, 2002; Domsch, 2009; Tschannen-Moran \& Gareis, 2004). Other research efforts find non-significant relationships between principal efficacy expectation and student achievement (Aderhold, 2005; Santamaria, 2008; McCullers, 2009; Moak, 2010; Gilmore, 2009). Despite these mixed findings, selfefficacy expectation has received more attention in research than outcome expectation even though Bandura (1977) has described both as integral in the social cognitive theory. In this study, the focus of investigation was to isolate and look at self-efficacy expectation separate from outcome expectation with the intention to determine the independent impacts of both. Although self-efficacy has received greater levels of attention in research, outcome expectation is emerging as a phenomenon in school leadership accountability, specifically in the state of Illinois - US where school leaders are required by law to set goal expectations of their students in academic achievement prior to teaching and assessment. Although there is limited research to support the impact of outcome expectation, this law has fomented opportunity to investigate the impacts of outcome expectation on academic achievement in K-12.

\section{Literature Review}

\section{The Principalship, Efficacy Expectation, Outcome Expectation, and Academic Outcomes}

The nexus between the complexity of the changing roles of school principals and the accountability movement has created the need to pre-determine principals' capacity to influence the improvement of student learning. Research continues to suggest that leaders, specifically how they act are central to school improvement and student achievement (Ingersoll, Sirinides, \& Dougherty, 2018; Day \& Gurr, 2014). And because of the magnitude of demands on principals, Santamaria's research (2008) speaks to the seemingly insurmountable task of the principal as a school leader needing self-efficacy and accountability to attain and sustain success. She claims that, 
"Given federal accountability regulations and potential sanctions for schools not achieving at specified levels, there is an increase in the urgency for educational agencies to identify school leaders who not only possess competency in leadership ability, but who also hold the drive and motivation to overcome overwhelming obstacles" (p. 3).

Despite this assertion, educational agencies are hard pressed to find means of determining whether school leaders possess the competencies that lead to success in all schools or the resilience to overcome challenges that come with leading schools successfully. Like researchers, education agencies have questions that remain unanswered: what specific measureable characteristics would such a principal exhibit? Or what should school boards/employers be looking for as evidence of drive or motivation to be successful? Or how should principal preparation programs equip candidates with skills to anticipate and act in ways that create success?

Given that principals guide the moral purpose for success of every student, there is a need to be able to predict not only principals' abilities and capacities to have positive influence on student achievement, but also foresight that will inspire their actions for success over time. Tschannen-Moran \& Gareis (2004) suggest that because the role of the school principal is increasingly defined by levels of "academic achievement and success as measured by high-stakes assessment results, a principal's sense of efficacy plays a critical role in meeting the expectations and demands of the position" (p. 582). Santamaria (2008) adds that a principal's "level of self-efficacy or belief in his or her own ability to achieve success" is what "determines whether or not those behaviors will lead to successful outcomes" (p. 3).

Substantial evidence supports the effects that self-efficacy beliefs have upon many individuals in their varied roles including the role of school leaders in student achievement (Liethwood \& Jantzi, 2008). For example, Wahlstrom, Seashore-Louis, Leithwood, and Anderson (as cited in Versland, 2013) wrote:

"Self-efficacy was a necessary component of successful school leadership because it affects choices principals make about what activities in which to engage as well as the coping strategies they employ as challenges emerge. They concluded that principals' sense of efficacy and their ability to influence others was vital to accomplishing instructional leadership practices associated with setting direction, developing people, redesigning the organization and managing the instructional program" (p. 14).

Based on this assertion, it can be assumed that research has established the connection between self-efficacy and school leadership (Mesterova, Prochazka, \&Vaculik, 2015; McCormick, Tanguma, \& Lopez-Forment, 2002). McCormick et al. (2002) found causal influence of self-efficacy on work performance in general and suggested extending self-efficacy to leadership studies. Mesterova et al. (2015) research suggests that effective leaders are set apart by what is likely their high levels of self-efficacy or belief in their capacity to perform the job, or task; 
the assumption being that effective leaders are "better equipped to handle various situations and may transfer their efficacy to their followers, resulting in superior group performance" (p. 112). In a quantitative study, Hughes (2010) found significantly higher levels of self-efficacy among principals who had attended leadership preparation programs, specifically in school management/leadership. However, this was not the case in instructional leadership. These findings suggest that principals exit preparation programs feeling better prepared to be managers in schools than to be instructional leaders who impact teachers and students' levels of achievement. In another study involving 241 elementary school principals in South Dakota, Aderhold's (2005) findings indicated no significant relationship between principal self-efficacy and student achievement in reading. Similarly, in a study with 218 principals, Domsch (2009) found no significant statistical relationship between the principals' self-efficacy and student achievement regardless of student grade level. Even in Moak's quantitative study of 123 respondents (2010) where Tschannen-Moran \& Gareis' (2004) Principal SelfEfficacy Scale (PSES) was broken down into its three domains, instructional leadership, management, and moral leadership; no statistically significant relationship was found between principal self-efficacy and student achievement. Even after factoring in principals' years of experience in the relationship between principal self-efficacy and student achievement, Gilmore (2009) found no significant statistical relationship. Other studies show different results. Lehman (2007) used quantitative analysis to examine the relationship between principals' self-efficacy and student achievement levels in reading $(\mathrm{n}=361)$ and found a statistically significant relationship, especially among schools with high populations on free and reduced lunch, a measure of poverty. Another study by Lovell (2009) examined the relationship between principals' levels of self-efficacy and student achievement of middle school students' in math and found statistically significant relationship. Another study found principals' self-efficacy to predict student achievement (Szymendera, 2013). The researcher stated,

"Self-efficacy contributed significantly to the criterion set. Principals with stronger beliefs in their capabilities as instructional and moral leaders, as well as in their management, were more likely to behave in ways that could indirectly or directly affect student achievemen"t (p. 75)

But despite the inclusion of outcome expectation in Bandura's theory (1977; 1989; 2006) and Williams' (2010) research, little research has focused on outcome expectation compared to self-efficacy, even as legislation has shifted to require principals to state outcome expectations of their students. In the state of Illinois, US, principals are required to provide information on expected outcome in terms of the percentage of students expected to meet and exceed expectations in reading and math. In support of using outcome expectation, Pajares (1996) claimed that "individuals infer their efficacy beliefs from imagined outcomes" (p. 559). Pajeres continues to explain that "individual's perception of the outcome and his value of the task necessary to achieve that outcome will regulate his behavior as powerfully as his self-efficacy beliefs and independently of them" (p. 559). In this sense, 
Pajares (1996) makes the claim that outcome expectation comes prior to efficacy expectation or operates independently of efficacy expectation. Williams (2010) brought this argument back into the research arena claiming that inattention to the contradiction between Pajera and Bandura, "has led to a disproportionate focus on self-efficacy as a causal determinant of behavior at the expense of expected outcomes" (p. 418).

Kirsch \& Baker as cited in Williams (2010) conducted research that demonstrated that outcome expectancies do, in fact, influence self-efficacy. Furthermore, Williams (2010) explained that expected outcomes influence selfefficacy ratings even when the context for behavior has not been considered. Williams calls into question whether or not these two variables may operate independently of one another. According to Williams, Bandura conceded that selfefficacy judgements can be casually influenced by outcome expectation (Williams, 2010, p. 420). Williams (2010) argued that current self-efficacy theory that is consistent with Bandura's (1977) original claims abates the evidence that outcome expectation does influence self-efficacy. He further claims that this condition exacerbates self-efficacy research "at the expense of attention to outcome expectancies in the context of theoretical models and as targets of behavior change intervention" (p. 421). Ultimately, Williams (2010) contends that to reconcile this issue, researchers should modify the operational definition of self-efficacy to be independent of expected outcome or to be influenced by the expected outcome. Either way, the current practice of researching self-efficacy theory implying selfefficacy expectation predicts and heavily influences outcome expectation (Bandura, 2000), should be questioned and researchers need to "be clear about their theoretical position regarding self-efficacy and outcome expectations" (Williams, 2010, p. 422).

As schools move forward with consideration for how to address principal self-efficacy and its relationship with student achievement (Lehman, 2007), consideration should be given to areas that research has not focused on to discover untapped potential for change. Several instruments have been developed to measure self-efficacy. In their quest for an instrument to measure principal selfefficacy, Tschannen-Moran and Gareis (2004) developed the Principal SelfEfficacy Scale (PSES), "a reasonably valid and reliable measure to capture this promising construct" (p. 575). Three themes as they relate to principal selfefficacy emerged from the PSES: efficacy for management, efficacy for instructional leadership, and efficacy for moral leadership. In their research, Tschannen-Moran and Gareis (2004) concluded that "Principals with a strong sense of self-efficacy have been found to be persistent in pursuing their goals but are also more flexible and more willing to adapt to strategies to meeting contextual conditions" (p. 574). In addition to efficacy expectation and the availability of data on outcome expectation in Illinois schools, this study focused on both self-efficacy and outcome expectation.

\section{Conceptual Framework}

Bandura (1977) developed the social cognitive theory, originally termed social 
learning theory. Later, Bandura (1989) explained that the interaction between behavior, personal factors, and the environment operate as interacting determinants that influence each other bi-directionally. Bi-directional relationship between each of the three factors indicates that people are as much producers of behavior as they are products of the behavior. The central tenet of social cognitive theory is that learning occurs in a social context with reciprocal interactions among the individual, their environment, and their behavior. Succinctly, "what people think, believe, and feel, affects how they behave" (Bandura, 1989, p.3).

From his social cognitive theory, Bandura (1977) developed the theory of self-efficacy, an individual's belief in their capacity to execute behaviors necessary to produce specific performance attainments. In his explanation of self-efficacy, Bandura (1977) contends that beliefs have greater influence on behavior than reinforcement. Therefore, an integral component of Bandura's self-efficacy theory centers on expectation beliefs because they shape behavior. He defines two kinds of expectations, outcome and efficacy expectations. Outcome expectation is the estimate that certain behaviors will lead to certain outcomes while efficacy expectation is a person's conviction of being able, or not able, to execute behavior that is necessary to produce a particular outcome (Bandura, 1977). Basically:

"outcome and efficacy expectations are differentiated, because individuals can believe that a particular course of actions will produce certain outcomes, but if they entertain serious doubts about whether they can perform the necessary activities such information does not influence their behavior" (Bandura, 1977, p. 193).

Outcome expectancy is predicated on the estimate that a person believes that by engaging in a behavior, a specific outcome will occur (Bandura, 1977). Given Bandura's theory, it may be assumed that outcome expectation precedes efficacy expectation (Bandura, 2006). For example, positive expectancies serve as incentives when previous behavior patterns produced positive outcomes, while negative expectancies serve as disincentives when previous behavior patterns produced negative outcomes. Generally, when individuals observe consequences of success, they are likely to have an outcome expectation of succeeding in a similar or related situation. Conversely, people tend to have negative outcome expectations and avoid situations where they have experienced or observed failure. And therefore, "Outcomes affect motivation and action largely by creating beliefs about the effects actions are likely to have under different circumstances" (Bandura, 1989, p. 40). In addition, outcomes exert influence through forethought without which, actors/leaders' motivation and ingenuity may not be used fully. Although, "outcomes people anticipate depend largely on their judgments of how well they will be able to perform in given situations" (Bandura, 2006, p. 309), it can be argued that people will put greater effort to achieve expected outcomes.

There are contradictory views on which of efficacy expectation or outcome expectation influence the other. In discussing efficacy and outcome expectations, Bandura (2000) claims that efficacy expectations influence outcome expectations because efficacy beliefs persuade people to determine and work towards goals. In 
other words, outcome expectancy depends on the levels of confidence a person has that by engaging in a behavior, a specific outcome will occur (Bandura, 1977; Bandura, Adams, \& Beyer, 1977). Therefore, efficacy expectancy determines "how much effort people will expend and how long they will persist in the face of obstacles and aversive experiences" (Bandura, 1977, p. 126) to meet their objective. It is "the conviction that one can successfully execute the behavior required to produce the outcomes" (Bandura, 1977, p. 193). By this definition, a stronger sense of efficacy to execute will produce greater efforts, persistence, and outcomes. If one perseveres in a subjectively difficult activity, it will improve self-efficacy, and in turn, the individual learns how to manage those situations, diminishing protective behaviors. Those who do not persevere will keep their self-hampering expectations (Bandura et al., 1977).

Unlike Bandura, other research (Williams, 2010) contend that outcome expectancy causally influences efficacy expectancy and not vice-versa. According to Williams (2010),

"Either the operational definition of self-efficacy must be modified such that expected outcomes cannot influence self-efficacy (consistent with current conceptualizations of self-efficacy theory) or self-efficacy theory must be modified such that outcome expectancies can influence self-efficacy (consistent with empirical findings using current operationalizations of selfefficacy)" (p. 421)

Although Bandura has challenged this argument, self-efficacy judgments remain causally influenced by expected outcomes (Williams, 2010). It is important to make clear that outcome expectation is not the same as actual outcome, just as "self-efficacy is involved with perceived capability rather than actual capability" (Williams, 2010, p. 418). Given the contradictions in research findings, this study examined, as suggested by Williams (2010) the independent influences of outcome expectation and efficacy expectation among elementary school principals on student behavior (academic achievement).

\section{Methodology}

A quantitative approach was utilized to achieve the goals of this study. Principal Self-Efficacy Scale (PSES) (Tschannen-Moran \& Gareis, 2004) was the survey instrument used to gather data from elementary school principals. Included in the survey was a question about expected outcome (anticipated student academic achievement). Surveys "help identify important beliefs and attitudes of individuals" (Creswell, 2012, p. 377). The target population for this study was elementary school principals throughout Illinois. The Illinois Public School Directory of 2016 reported 2,605 elementary schools in the state of Illinois. Single random sampling procedure was used to identify a sample. Principals' emails were obtained by permission through the Illinois Principals Association and participants were contacted through email. 
An online survey design was used to collect data on perceptions of elementary school principals (self-efficacy), principal's expectation in terms of percent of students meeting and exceeding state set expectations, and actual percentage of students meeting and exceeding the state set expectations on the Partnership for Assessment of Readiness for College and Careers (PAARCC). Participants had access to a hyper link of the web-based survey. Included in the hyper link were, an introductory letter with instructions, consent form, and the PSES. Other items requested of the respondents were, respondent demographic data, school demographic data, and percentage of students from low socio-economic-status. PSES is an 18 item Likert-scale measure that assesses levels of efficacy of a school leader (Tschannen-Moran \& Gareis, 2004).

Construct validity of the Principal Self-Efficacy Survey (PSES) was determined by correlating the instrument against other known constructs (work alienation, $r=-0.45 ; p<0: 01$; trust in teachers, $r=0.42, p<0: 01$; and trust in students and parents, $\mathrm{r}=0.47 ; \mathrm{p}<0: 01$ ) (Tschannen-Moran \& Gareis, 2004). Reliability based on Cronbach's alpha were: .789 (management efficacy); .832 (instructional leadership efficacy); and .785 (moral leadership efficacy) (Lehman, 2007, p. 50). PSES Cronbach Alpha reliability coefficient for this study was reported as follows: Management Efficacy (.99); Instructional Leadership Efficacy (98); and Moral Leadership Efficacy (.98). Data collected was analyzed using both descriptive statistical and inferential statistical statistics.

\section{Findings}

The purpose of this study was to investigate the independent influence of selfefficacy expectation and outcome expectation on student achievement using data from elementary school principals. Descriptive data (Table 1) indicated that the expected outcome mean score on student academic achievement was higher than actual outcome mean score for the sample and for all demographic types. Female principals mean scores were higher than male mean scores on all variables including expected and actual academic outcome mean scores. Principals with advanced degrees scored higher than principals with Master's degrees on all variables. Principals in Sub-urban and Unit School Districts (K-12) scored consistently higher than principals in Rural School Districts and Elementary School Districts (K-6) on all variables respectively. 
Table 1. Descriptive Data by Demographics

\begin{tabular}{|c|c|c|c|c|c|c|}
\hline \multicolumn{7}{|c|}{ Component of self-efficacy } \\
\hline & $\begin{array}{l}\text { Expected } \\
\text { Outcomes }\end{array}$ & $\begin{array}{c}\text { Actual } \\
\text { outcomes }\end{array}$ & $\begin{array}{c}\text { Self- } \\
\text { efficacy } \\
\text { composite }\end{array}$ & $\begin{array}{c}\text { Instructional } \\
\text { leadership }\end{array}$ & Management & $\begin{array}{c}\text { Moral } \\
\text { leadership }\end{array}$ \\
\hline $\begin{array}{l}\text { Sample } \\
(205)\end{array}$ & $\begin{array}{c}49.03 \\
(18.91) \\
\end{array}$ & $\begin{array}{c}44.59 \\
(19.06) \\
\end{array}$ & $\begin{array}{c}7.09 \\
(1.35) \\
\end{array}$ & $\begin{array}{c}6.33 \\
(1.02) \\
\end{array}$ & $\begin{array}{c}6.43 \\
(1.64) \\
\end{array}$ & $\begin{array}{c}7.54 \\
(1.25) \\
\end{array}$ \\
\hline \multicolumn{7}{|l|}{ Gender } \\
\hline Males (97) & $\begin{array}{c}48.11 \\
(19.69)\end{array}$ & $\begin{array}{c}42.86 \\
(18.79)\end{array}$ & $\begin{array}{c}5.96 \\
(0.97)\end{array}$ & $\begin{array}{c}5.45 \\
(0.68)\end{array}$ & $\begin{array}{c}5.04 \\
(1.16)\end{array}$ & $\begin{array}{c}6.50 \\
(0.99)\end{array}$ \\
\hline $\begin{array}{l}\text { Females } \\
\text { (126) }\end{array}$ & $\begin{array}{c}50.22 \\
(18.07)\end{array}$ & $\begin{array}{c}46.44 \\
(19.23)\end{array}$ & $\begin{array}{c}8.13 \\
(0.59)\end{array}$ & $\begin{array}{c}7.12 \\
(0.49)\end{array}$ & $\begin{array}{c}7.69 \\
(0.76)\end{array}$ & $\begin{array}{c}8.47 \\
(0.48)\end{array}$ \\
\hline \multicolumn{7}{|l|}{$\begin{array}{l}\text { Years of } \\
\text { Experience }\end{array}$} \\
\hline $0-5(73)$ & $\begin{array}{c}47.37 \\
(18.88)\end{array}$ & $\begin{array}{c}42.02 \\
(19.29)\end{array}$ & $\begin{array}{c}6.95 \\
(1.52)\end{array}$ & $\begin{array}{c}6.22 \\
(1.14)\end{array}$ & $\begin{array}{c}6.25 \\
(1.82)\end{array}$ & $\begin{array}{c}7.40 \\
(1.45)\end{array}$ \\
\hline $6-10(72)$ & $\begin{array}{c}47.47 \\
(18.64)\end{array}$ & $\begin{array}{c}46.78 \\
(20.05)\end{array}$ & $\begin{array}{c}6.94 \\
(1.35)\end{array}$ & $\begin{array}{c}6.22 \\
(1.03)\end{array}$ & $\begin{array}{c}6.24 \\
(1.65)\end{array}$ & $\begin{array}{c}7.41 \\
(1.26)\end{array}$ \\
\hline $11-15$ (49) & $\begin{array}{c}53.19 \\
(17.83)\end{array}$ & $\begin{array}{c}46.05(16.6 \\
7)\end{array}$ & $\begin{array}{c}7.26 \\
(1.11)\end{array}$ & $\begin{array}{c}6.44 \\
(0.87)\end{array}$ & $\begin{array}{c}6.44 \\
(1.39)\end{array}$ & $\begin{array}{c}7.67 \\
(0.96)\end{array}$ \\
\hline $16-20(17)$ & $\begin{array}{c}47.58 \\
(17.01)\end{array}$ & $\begin{array}{c}41.18 \\
(18.84)\end{array}$ & $\begin{array}{c}7.36 \\
(1.23)\end{array}$ & $\begin{array}{c}6.51 \\
(0.93)\end{array}$ & $\begin{array}{c}6.75 \\
(1.52)\end{array}$ & $\begin{array}{c}7.79 \\
(1.11)\end{array}$ \\
\hline $21+(11)$ & $\begin{array}{c}54.22 \\
(28.11) \\
\end{array}$ & $\begin{array}{c}46.28 \\
(22.65) \\
\end{array}$ & $\begin{array}{c}7.69 \\
(1.51) \\
\end{array}$ & $\begin{array}{c}6.78 \\
(0.87) \\
\end{array}$ & $\begin{array}{c}7.12 \\
(1.47) \\
\end{array}$ & $\begin{array}{c}8.08 \\
(0.98) \\
\end{array}$ \\
\hline \multicolumn{7}{|l|}{ Education } \\
\hline $\begin{array}{l}\text { Masters } \\
(132)\end{array}$ & $\begin{array}{c}47.83 \\
(19.20)\end{array}$ & $\begin{array}{c}42.77 \\
(18.56)\end{array}$ & $\begin{array}{c}6.53 \\
(1.07) \\
\end{array}$ & $\begin{array}{c}5.73 \\
(0.77) \\
\end{array}$ & $\begin{array}{c}5.53 \\
(1.29) \\
\end{array}$ & $\begin{array}{c}6.88 \\
(1.05) \\
\end{array}$ \\
\hline $\begin{array}{l}\text { Advanced } \\
\text { degree (91) }\end{array}$ & $\begin{array}{c}51.90 \\
(18.03) \\
\end{array}$ & $\begin{array}{c}48.92 \\
(19.72) \\
\end{array}$ & $\begin{array}{c}8.30 \\
(0.37) \\
\end{array}$ & $\begin{array}{c}7.30 \\
(0.23) \\
\end{array}$ & $\begin{array}{c}7.82 \\
(0.41) \\
\end{array}$ & $\begin{array}{c}8.64 \\
(0.38) \\
\end{array}$ \\
\hline \multicolumn{7}{|l|}{ Context } \\
\hline Rural (83) & $\begin{array}{c}47.91 \\
(19.60)\end{array}$ & $\begin{array}{c}43.20 \\
(19.21)\end{array}$ & $\begin{array}{c}5.77 \\
(0.93)\end{array}$ & $\begin{array}{c}5.32 \\
(0.66)\end{array}$ & $\begin{array}{c}6.33 \\
(0.96)\end{array}$ & $\begin{array}{c}4.81 \\
(1.10)\end{array}$ \\
\hline $\begin{array}{l}\text { Sub-Urban } \\
\text { (117) }\end{array}$ & $\begin{array}{c}49.92 \\
(18.37)\end{array}$ & $\begin{array}{c}45.68 \\
(18.97)\end{array}$ & $\begin{array}{l}7.98 \\
(0.93)\end{array}$ & $\begin{array}{c}6.99 \\
(0.55)\end{array}$ & $\begin{array}{c}8.34 \\
(0.35)\end{array}$ & $\begin{array}{c}7.51 \\
(0.79)\end{array}$ \\
\hline \multicolumn{7}{|l|}{$\begin{array}{l}\text { Type of } \\
\text { school }\end{array}$} \\
\hline $\begin{array}{l}\text { Elementary } \\
\text { District } \\
(127)\end{array}$ & $\begin{array}{c}47.76 \\
(19.32)\end{array}$ & $\begin{array}{c}42.65 \\
(18.71)\end{array}$ & $\begin{array}{c}6.38 \\
(1.05)\end{array}$ & $\begin{array}{c}5.69 \\
(0.74)\end{array}$ & $\begin{array}{c}5.48 \\
(91.28)\end{array}$ & $\begin{array}{c}6.83 \\
(1.05)\end{array}$ \\
\hline $\begin{array}{l}\text { Unit District } \\
(98)\end{array}$ & $\begin{array}{c}51.73 \\
(17.85) \\
\end{array}$ & $\begin{array}{c}48.68 \\
(19.31) \\
\end{array}$ & $\begin{array}{c}8.41 \\
(0.45) \\
\end{array}$ & $\begin{array}{c}7.38 \\
(0.28) \\
\end{array}$ & $\begin{array}{c}8.02 \\
(0.64) \\
\end{array}$ & $\begin{array}{c}8.86 \\
(0.40) \\
\end{array}$ \\
\hline \multicolumn{7}{|l|}{$\%$ Poverty } \\
\hline $0-25 \%(75)$ & $\begin{array}{c}54.16 \\
(16.85)\end{array}$ & $\begin{array}{c}48.28 \\
(19.34)\end{array}$ & $\begin{array}{c}7.23 \\
(1.23)\end{array}$ & $\begin{array}{c}6.44 \\
(0.95)\end{array}$ & $\begin{array}{c}6.61 \\
(1.68)\end{array}$ & $\begin{array}{c}7.68 \\
(1.11)\end{array}$ \\
\hline $26-50 \%(61)$ & $\begin{array}{c}60.00 \\
(28.28)\end{array}$ & $\begin{array}{c}51.50 \\
(37.47)\end{array}$ & $\begin{array}{c}6.96 \\
(1.41)\end{array}$ & $\begin{array}{c}6.24 \\
(1.07)\end{array}$ & $\begin{array}{c}6.25 \\
(1.68)\end{array}$ & $\begin{array}{c}7.41 \\
(1.37)\end{array}$ \\
\hline $51 \% \&>(95)$ & $\begin{array}{l}55.55 \\
(7.77)\end{array}$ & $\begin{array}{c}51.00 \\
(16.97)\end{array}$ & $\begin{array}{c}7.11 \\
(1.28)\end{array}$ & $\begin{array}{c}6.33 \\
(0.97)\end{array}$ & $\begin{array}{c}6.46 \\
(1.56)\end{array}$ & $\begin{array}{c}7.56 \\
(1.18)\end{array}$ \\
\hline
\end{tabular}

Correlational analyses found high correlations among self-efficacy compo- 
nents, however very low but significant correlations were found between selfefficacy components including composite score with expected and actual academic outcomes. It was noted that expected outcome had the highest significant correlation with actual academic outcome $(r=.33 ; \mathrm{p}<.01)$.

Table 2. Correlations among Principal Self-Efficacy Composite Score, SelfEfficacy Sub Scales, expected and Actual PARCC 2016 Composite Scores

\begin{tabular}{|l|c|c|c|c|c|}
\hline & $\begin{array}{c}\text { Self- } \\
\text { Efficacy } \\
\text { Composite }\end{array}$ & $\begin{array}{c}\text { Moral } \\
\text { Leadership }\end{array}$ & $\begin{array}{c}\text { Instructional } \\
\text { Leadership }\end{array}$ & Management & $\begin{array}{c}\text { Expected } \\
\text { Outcomes }\end{array}$ \\
\hline & $(n=203)$ & $(n=205)$ & $(n=204)$ & $(n=203)$ & $(n=186)$ \\
\hline $\begin{array}{l}\text { Moral } \\
\text { Leadership }\end{array}$ & & & & & \\
\hline $\begin{array}{l}\text { Instructional } \\
\text { Leadership }\end{array}$ & $.99 * *$ & $.98^{* *}$ & & & \\
\hline Management & $.99 * *$ & $.98^{* *}$ & $.99 * *$ & $.14^{*}$ & \\
\hline $\begin{array}{l}\text { Expected } \\
\text { Outcomes }\end{array}$ & $.14 * *$ & $.13^{*}$ & $.15^{*}$ & $.14^{*}$ & $.33 * *$ \\
\hline $\begin{array}{l}\text { Actual } \\
\text { Outcomes }\end{array}$ & $.14 * *$ & $.14^{* *}$ & $.15^{*}$ & & \\
\hline
\end{tabular}

${ }^{*} p<.05$, two-tailed. $* * p<.01$, two-tailed.

Regression analysis (Table 3) indicated that expected outcome was the only predictor of actual academic outcome (actual PARCC).

Table 3. Regression Analysis of Actual PARCC 2016 Composite Scores $(n=186)$ base on Self-Efficacy Composite Scores, Sub Scales and Expected PARCC 2016 Composite Scores

\begin{tabular}{|l|c|c|c|c|}
\hline Variable & $\boldsymbol{B}$ & $\boldsymbol{S E} \boldsymbol{B}$ & $\boldsymbol{B}$ & Sig. \\
\hline Step 1 & & & & \\
\hline Constant & .67 & 1.11 & & \\
\hline Composite Self-Efficacy & 7.54 & 5.17 & 10.20 & .15 \\
\hline $\begin{array}{l}\text { Instructional Leadership Self- } \\
\text { Efficacy }\end{array}$ & -2.58 & 2.07 & -2.66 & .22 \\
\hline Moral Leadership Self-Efficacy & -2.52 & 1.73 & -3.25 & .15 \\
\hline Management Self-Efficacy & -2.65 & 1.74 & -4.26 & .13 \\
\hline Expected PARCC 2016 Composite & .28 & .07 & .28 & .00 \\
\hline
\end{tabular}

Note: $R^{2}=.11$ for Step $1, p<.05$

\section{Discussions and Conclusion}

A framework presented for this study asserts that principals' self-efficacy and principals' outcome expectation act independently of one another insofar as their impact on student achievement is concerned. Findings from this study indicate both principals' self-efficacy and principals' outcome expectation correlate positively to student achievement and act independently of one another. Specifically, principals' outcome expectation was found to significantly impact student 
achievement, whereas principals' self-efficacy did not, as evident in the regression analysis. The dichotomy in results from this study substantiates Pajares' (1996) claim that both self-efficacy expectation and outcome expectation may in fact act independently of one another. Ultimately, results from this study raise further questions about why available research on principal self-efficacy and its impact on student achievement excludes outcome expectation, specifically as it relates to school principals. It may be argued that the absence of outcome expectation data in schools contributes to the scarcity of studies focusing on outcome expectation. This study was possible because of the existence of a policy requiring all principals in the state of Illinois to state their expected school outcome. The availability of such data is important for this type of research.

Research in the area of principal self-efficacy and its impact on student achievement has been influenced to a large extent by Tschannen-Moran and Gareis' study (2004) where a reliable instrument, the Principal Self-Efficacy Scale (PSES) was developed to measure principal efficacy, specifically in the areas of instructional leadership, moral leadership and management. Studies utilizing the PSES, specifically studies by Aderhold (2005), Lovell (2009), and Szymendera (2013) demonstrated mixed results with respect to principal efficacy as a predictor of student achievement.

Utilization of the PSES in this study found that among elementary school principals, perceived self-efficacy for moral leadership was higher than perceived self-efficacy for instructional leadership along with perceived self-efficacy for management leadership. Firestone and Riehl (2005), Wagner and Simpson (2009), and Pede (2015) suggested that morality among principals is a guiding force in all of their decision-making. Because of this, moral leadership also known as ethical leadership is emphasized in principal preparation programs and is a focus in the standards for school leadership practice and leadership preparation. Ultimately, even though this study found that elementary school principals possess a heightened sense of moral leadership, it had minimal impact on student achievement. This does not necessarily mean that moral leadership is not signifycant in student achievement, it is possible that its impact on student achievement is indirect. According to Ingersoll, Sirinides, and Doughery (2018), leadership, including moral leadership only matters in student achievement when it "actively involves teachers in decision making, and that these are tied to higher student achievement" (p. 17). In other words, morality that does not engage teachers in aspects of school leadership and decision making, may have minimal effects on student outcome.

As we concluded this study, it was evident that whereas a plethora of research exists in education showing the impacts of self-efficacy, principal characteristics, and school demographics on student achievement; research searches for this study found limited research on outcome expectation alongside efficacy expectation, specifically research seeking to determine the independent impacts of efficacy and outcome expectations on student achievement. Bandura (1977) explains that outcome expectation is indispensable to his theory because a person's efficacy expectation leads him/her to execute behavior that in turn influences his/her outcome expectation leading to the actual outcome. Relevant to the discussion on 
outcome expectation and this study's findings, Bandura (as cited in Fouad \& Guillen, 2006) noted, "The more value or importance an individual placed on the outcome expectations, the greater the likelihood the individual would engage in the behavior" (p. 133). Given this claim, the correlation between elementary school principals' expected outcome on PARCC 2016 composite score and actual PARCC 2016 composite score $(r=.33, \mathrm{p}<.01)$, and the fact that outcome expectation was a predictor of academic outcomes, suggest that principals in this study placed value and importance on their outcome expectation for student achievement and, consequently, engaged in behaviors necessary to attain their expected levels of student achievement.

The question the remains is why research has not focused on outcome expectation? Evidence that may explain why outcome expectation has not been examined in educational leadership research can be extrapolated from the research of Lent et al. (1994), as cited in Fouad and Guillen, (2006). Here, "Self-efficacy is hypothesized to determine outcome expectations" (p. 134). In other words, if an individual's self-efficacy is high, so will be their outcome expectation, thereby negating the need to study both variables' and their impacts on behavior. Given that Bandura acknowledges the need to study both outcome expectation and selfefficacy together to better predict human behavior, there is need for more studies that include outcome expectation. This study focused on both variables in seeking to establish the independence of each and the independence of their impacts on student achievement.

The findings of this study support claims by Parajes (1996), "that an individual's perception of the outcome and his value of the task necessary to achieve that outcome will regulate his behavior as powerfully as his self-efficacy beliefs, and independently of them" (p. 559). This claim is the reason this research study was designed. It is important to note that despite the controversy over which variable influences which in Bandura's theory, limited research studies exist in education that have investigated efficacy and outcome expectation together. Furthermore, research continues to neglect outcome expectation, not simply as part of Bandura's original theory, but also as a possible separate variable (Agunbiade, 2015).

Notably, this research study's framework demonstrates that both principals' self-efficacy and principals' outcome expectation influence actual outcome and thereby supports Bandura's social cognitive theory (1977). However, the findings of this study are aligned to the claim by Parajes (1996) that outcome expectation and self-efficacy also act independently of one another with only outcome expectation predicting actual academic outcome.

It is critical that more research is under-taken in this area of study to enhance our understanding of the impacts of outcome expectation on student achievement and the work of principals. Future directions for research could include the variable of principal outcome expectation in studies focusing on teacher and principal self-efficacy and their impacts on student achievement. Additionally, moving forward, new research could include the impact of principal outcome expectation, along with principal self-efficacy expectations on teacher job satisfaction and retention. 
Findings of this study indicate that we should not accept the notion that selfefficacy is a better predictor of actual outcome than outcome expectation and continue to study principal self-efficacy and its impact on student achievement without regard for the role outcome expectation. Doing so may cause missed opportunities to discover new ways to influence student achievement and leverage principals' influences. The findings of this study demonstrate that there is a high chance that principal outcome expectation has significant impact on student achievement independent of principal self-efficacy.

\section{References}

Aderhold, F. (2005). Principal efficacy, student reading achievement, and instructional Leadership behavior in South Dakota elementary schools (Doctoral Dissertation). Retrieved from ProQuest Dissertations (UMI No. 3188175).

Agunbiade, A. (2015). An examination of high school principals' perceived self-efficacy and student achievement (Doctoral Dissertation). Retrieved from ProQuest Dissertations (UMI No. 3737386).

Bandura, A. (1977). Self-efficacy: Toward a unifying theory of behavioral change. Psychological Review, 84(2), 191-215.

Bandura, A. (1989). Social cognitive theory. In R. Vasta (Ed.) Annals of Child Development, vol. 6, (pp. 1-60). Greenwich, CT: JAI Press.

Bandura, A. (2000). Cultivate self-efficacy for personal and organizational effectiveness (pp. 179-200). In E.A. Locke (Ed). Handbook of principals of organization behavior $\left(2^{\text {nd }}\right.$ ed.). New York: Wiley.

Bandura, A. (2006). Self-efficacy beliefs in adolescents. Greenwich, CT: Information Age Publishing.

Bandura, A., Adams, N.E., \& Beyer, J. (1977). Cognitive processes mediating behavioral change. Journal of Personality and Social Psychology, 35(3), 125-139.

Bryk, A.S., Sebring, P.B., Allensworth, E., Luppescu, S. \& Easton, J.Q. (2010). Organizing schools for improvement: lessons from Chicago. Chicago, IL: The University of Chicago Press.

Creswell, J.W. (2014). Research design: Qualitative, quantitative, and mixed methods approach. Thousand Oaks, CA: Sage Publications.

Day, C. \& Gurr, D. (2014). Leading schools successfully (pp.1-6). In C. Day \& D. Gurr, Leading schools successfully: Stories from the field. New York: Routledge.

Domsch, G.D. (2009). A study investigating relationships between Elementary principals' and teachers' self-efficacy and student achievement (Doctoral Dissertation). Retrieved from ProQuest Dissertations. (UMI No. 3383305).

Firestone, W. \& Riehl, C. (2005). A new agenda for research in educational leadership. New York: Teachers College Press.

Fouad, N., \& Guillen, A. (2006). Outcome expectations: Looking to the past and potential future. Journal of Career Assessment, 14(1), 130-142.

Gilmore, J.M. (2009). The role of the principal in affecting student achievement (Doctoral Dissertation). Retrieved from ProQuest Dissertations. (UMI No. 3357421).

Gist, M.E. \& Mitchell, T.R. (1992). Self-Efficacy: A Theoretical analysis of its determinants and malleability. The Academy of Management Review, 17(2), 183-211.

Goldring, E., Cravens, X.C, Murphy, J., Porter, A.C., Elliot, S.N., \& Carson, B. (2009). The evaluation of principals: What and how do states and urban districts assess leadership? The Elementary School Journal, 110(1), 19-39. 
Grissom, J., \& Loeb, S. (2009). Triangulating principal effectiveness: How perspectives of parents, teachers, and assistant principals identify the central importance of managerial skills. Retrieved from https://urbn.is/2UFsf7W.

Hughes, L.L. (2010). The principalship: Preparation programs and the self-efficacy of principals (Doctoral Dissertations). Retrieved from ProQuest Dissertations. (UMI No. 3397437).

Ingersoll, R.M., Sirinides, P., \& Dougherty, P. (2018). Leadership matters: Teachers' roles in school decision making and school performance. American Educator, 42(1), 1318.

Krzemienski, J. (2012). The impact of stress on Elementary school principals and their effective coping mechanisms (Doctoral Dissertation). Retrieved from ProQuest Dissertations. (UMI No. 3536496).

Lehman, R. (2007). The relationship of Elementary school principals' perceptions of selfefficacy and student achievement (Doctoral Dissertation). Retrieved from ProQuest Dissertations. (UMI No. 3262932).

Leithwood, K., \& Jantzi, D. (2008). Linking leadership to student learning: The contributions of leader efficacy, Educational Administration Quarterly, 44(4), 496528.

Lovell, C.W. (2009). Principal efficacy: An investigation of school principals' sense of efficacy and indicators of school effectiveness (Doctoral Dissertation). Retrieved from ProQuest Dissertations. (UMI No. 3396135).

Moak, J. (2010). The self perception of leadership efficacy of elementary principals and the effects on student achievement (Doctoral Dissertation). University of Missouri, Columbia.

McCormick, M.J., Tanguma, J., \& Lopez-Forment, A.S. (2002). Extending self-efficacy theory to leadership: A review and empirical test. Journal of Leadership Education, $1(2), 34-49$.

McCullers, J.F. (2009). Self-efficacy beliefs of Florida school principals regarding Federal and State accountability measures (Doctoral Dissertation). Retrieved from ProQuest Dissertations. (UMI No. 3401089).

Mesterova, J., Prochazka, J., \& Vaculik, M. (2015). Relationship between self-efficacy, transformational leadership and leader effectiveness. Journal of Advanced Management Science, 3(2), 109-122. doi: 10.12720/joams.3.2.109-122.

Norton, M. S. (2002). Let's keep our quality principals on the job. The High School Journal, 86(2), 50-56.

Paglis, L.L., \& Green, S.G. (2002). Leadership self-efficacy and managers' motivation for leading change. Journal of Organizational Behavior, 23(2), 215-235. doi: 10.1002/ job.137.

Pajares, F. (1996). Self-efficacy beliefs in academic settings. Review of Educational Research, 66(4), 543-578.

Pede, J. (2015). Morals, values and ethics: Their impact on the decisions of the school principal (Doctoral Dissertation). Retrieved from ProQuest Dissertations (UMI No. 3687658).

Roley, S.E. (2009). Creativity, cultural proficiency and self-efficacy in rural school principals: The relationship to reducing the achievement gap for low-income students (Doctoral Dissertation). Retrieved from ProQuest Dissertations. (UMI No. 3344749).

Sanders, M.G. (2014). Principal leadership for school, family, and community partnerships: The role of a systems approach to reform implementation. American Journal of Education 120(2), 233-255.

Santamaria, A.P. (2008). A principal's sense of self-efficacy in an age of accountability (Doctoral Dissertation). Retrieved from ProQuest Dissertations. (UMI No. 3296855). 
Szymendera, M.T. (2013). The relationship between self-efficacy, school and personal characteristics, and principal behaviors related to affecting student achievement (Doctoral Dissertation). Retrieved from ProQuest Dissertations (UMI No. 3589934).

Troutman, L.D. (2012). The impact of principal leadership on school culture and student achievement (Doctoral Dissertation). Retrieved from ProQuest Dissertations. (UMI No. 3545656).

Tschannen-Moran, M., \& Gareis, C.R. (2004). Principals' sense of efficacy: Assessing a promising construct. Journal of Educational Administration, 42(5), 573-585. doi:10. $1108 / 09578230410554070$.

Versland, T.M. (2013). Principal efficacy: Implications for rural 'grow your own' leadership programs. Rural Educator, 35(1), 13-22.

Virga, J. Jr. (2012). Examining the perceptions and sources of the self-efficacy beliefs of principals of high-achieving elementary schools (Doctoral Dissertation). Retrieved from ProQuest Dissertations. (UMI No. 3543491).

Wagner, P., \& Simpson, D. (2009). Ethical decision making in school administration: Leadership as moral architecture. Los Angeles: Sage.

Williams, D.M. (2010). Outcome expectancy and self-efficacy: Theoretical implications of an unresolved contradiction. Personality and Social Psychology Review, 14(4), 417-425. 